\title{
The Effect of Accounting Information System and Internal Control System on the Quality of Financial Reports at PT Semen Baturaja (Persero) Tbk.
}

\author{
Ciko Arfismanda ${ }^{1}$, Maulan Irwadi $^{2}$, R.M. Rum Hendarmin ${ }^{3)}$ \\ 1), 2), 3) Pragram Studi Akuntansi, Universitas Indo Global Mandiri, Palembang, Indonesia \\ Email: ciko.chessmaster@gmail.com ${ }^{1)}$,irwadi1@yahoo.co.id ${ }^{2}$,hendarmin@uigm.ac.id ${ }^{3)}$
}

\begin{abstract}
This study aims to analyze partially and simultaneously the effect of accounting information systems and internal control systems on the quality of financial reports at PT. Semen Baturaja (Persero) Tbk. The data used came from observation and questionnaires to 60 respondents. This research method uses a quantitative approach using multiple linear regression. The results of the study partially show that both accounting information and internal control system variables have a significant positive effect on the quality of financial statements. The results of the study using the coefficient of determination (R2) obtained a value of 0.464 . This shows that the large contribution of the accounting information system and internal control system variables can explain the quality of financial statements by $46.4 \%$, the remaining $53.6 \%$ can be explained by other variables not included in this study.
\end{abstract}

Keywords: accounting information system, internal control system, quality of financial reports.

\section{Introduction}

\subsection{Background}

In this modern era, many companies are using increasingly advanced technology according to the development of this era. Where the company is one of the parties who need and keep up with the times. Along with the size of the company, with a manual system, the company will find it difficult to implement the company's performance, then the decision of the manager is able to determine whether the company will use more sophisticated methods and use the latest technology for the company or not. This sophisticated technology will help the company and employees a lot to make their performance more efficient and effective in implementing it.

One of the actions taken by the company to overcome competition between other competitors and face technological developments in modern times is to improve the quality of information and the use of accounting information systems. Information is needed because with good company information it will be able to help companies in making decisions. The development of a very modern world has to do with advances in information technology which significantly affects everything related to aspects of human life and business activities of a company.

An accounting information system is a series of components related to recording and processing accounting data into useful information for organizations in making decisions. The accounting information system in a company is the largest part of processing financial data from recording transaction activities that have occurred and then producing useful information for users to achieve goals (Deny, 2014). The application of accounting information systems is placed in an effort to achieve computerization in the company's organization to be more accurate, precise and comprehensive, so as to improve the quality of decisions taken by users of these financial statements.

The internal control system is a very important element in presenting financial statements and 
is the basis for safe, healthy, and growing operations that can grow naturally. The internal control system helps the company in safeguarding its assets. Not only that, the internal control system will ensure accurate and reliable financial and managerial reporting, optimize the use of resources economically and efficiently, improve compliance with provisions and legislation (Effendi, 2013)

According to COSO (The Committee Of Sponsoring Organizations of Treadway Commission), Internal control consists of five components, namely: control environment, risk assessment, control activities, information and communication, and monitoring. The internal control system is useful for the purpose of preventing or maintaining the occurrence of undesirable things (errors or frauds). Internal control functions to oversee all financial activities that occur in the company. Internal control can help the company and serve as a tool to implement control effectively. With the existence of internal control, managers can assure themselves that the information contained in the financial statements can be trusted.

Financial reports are a medium for a government entity to account for its financial performance to the public. Financial reports are said to be of high quality if the information presented in the financial statements is understandable, free from misleading understanding and material errors, presents facts honestly and can be verified. Based on Government Regulation No. 8/2006, financial statements are a form of accountability for state/regional financial management for one period. In order to produce quality financial reports, financial statements must meet adequate criteria, namely having relevance, being reliable, being able to be assessed or compared, and being understandable.

The quality of financial statements is considered to have benefits in making financial decisions because financial statements provide information for investors and creditors to help them predict the amount, timing, and uncertainty of future cash flows. Basically, the purpose of financial reporting is to assess the company's performance, it can be seen from the financial report data obtained by the company. Financial statement information has a relationship with the company's accounting information system, this shows that this accounting information system must be able to be controlled by the company in presenting financial statements, in order to produce accurate information and support the company's performance so that companies need accounting information systems and control systems.

PT Semen Baturaja (Persero) Tbk is a company engaged in the cement management industry in the South Sumatra region. This company has considerable attention in achieving the main goal of producing quality, efficient cement, and marketing it by prioritizing customer satisfaction and must also achieve optimal profit. Reporting financial statements is inseparable from the influence of an effective accounting information system and internal control system so that it can have a major influence on the quality of financial reports.

The phenomenon that occurs at PT Semen Baturaja (Persero) Tbk is related to the quality of financial reports that are less relevant, namely the case of late submission of interim financial reports to the Indonesia Stock Exchange. The delay in submitting the financial statements caused the company to be suspended and imposed a fine of $150,000,000$ rupiahs per quarter. From the Indonesia Stock Exchange (IDX) data in 2019, there were 50 issuers who were late in submitting financial reports on the IDX, one of which was PT. Semen Baturaja (Persero) Tbk (Sutrisna, 2020).

Based on previous research on accounting information systems and internal control systems on the quality of financial reports in the journal entitled "The Influence of Implementation of 
Accounting Information Systems, Internal Control Systems, and Human Resource Competencies on the Quality of Financial Reports of Regional Apparatus Work Units in Banda Aceh City Government" which states that internal control has a positive and significant effect on the quality of financial reports (Tawaqal \& Suparno, 2017). While this is contrary to the results of other studies which state that internal control has no effect on the quality of financial reports, in the Journal entitled "The Effect of Internal Control Systems and Regional Financial Accounting Systems on the Quality of Government Financial Reports" (Mokoginta \& Lambey, 2017).

\section{Literatur Review}

\subsection{Grand Theory}

\subsubsection{Theory Of Reasoned Action (TRA)}

Theory of Reasoned Action (TRA) is a deviation from previous studies which were originally from the theory of attitudes and behavior (Jogiyanto, 2007). This theory is a theory related to the attitudes and behavior of individuals in carrying out activities. TRA developed by subsequent studies resulted in a theory regarding the use of information systems. This theory is a technology acceptance model which is abbreviated as TAM (Technology Acceptance Model).

This model is a model of acceptance of information technology systems that will be used by users. The purpose of the TAM model is to be able to explain the main factors of the behavior of information technology users on the acceptance of the use of information systems. This model is expected to illustrate that the use of information systems will be influenced by the usability variable and the ease of use variable. Where this variable has a high determinant and validity which has been empirically tested by subsequent studies such as research by (Davis, 2018).

\subsubsection{Behavioral Research Theory}

In this field, it explains how users of accounting information make decisions and what information they need (Icek, 1991). Most of the research in this field uses research laboratories by conducting experiments. In this study, the researchers made Behavioral Research Theory as the main theory due to the use of accounting information systems in the income cycle, expenditure cycle, and human resource cycle applied by the company, used to improve accounting information used for company decision making in managing inventory management with information. generated from the accounting information system.

\subsection{Accounting information system}

An accounting information system is a system that processes data and transactions to produce useful information for planning, controlling and operating a business (Krismiaji, 2015). The accounting information system in a company is the largest part in processing financial data from recording transaction activities that have occurred and then producing useful information for users to achieve goals. The purpose of an accounting information system is to provide accounting information to various parties who need the information, both internally and externally.

The accounting information system as a system cannot stand alone, because it must relate to other information systems in the company. There are 6 components of the accounting information system, consisting of input components or input components, model/process 
components, information components or output components, database components, technology components and control components/control components.

\subsection{The internal control system}

The internal control system is defined by the AICPA (American Institute Of Certified Public Accountants) as the structure of an organization and all the organized methods and measures established within a company for the purpose of maintaining the security of company assets, checking the accuracy and correctness of accounting data, improve the operational efficiency of activities and encourage adherence to established policies.

COSO (The Committee of Sponsoring Organizations of Treadway Commission) is an initiative of the private sector that was formed in 1985. In 1992, COSO was established with the main objective to identify the factors that cause fraudulent financial statements and make recommendations to reduce its occurrence. has published an Internal Control Framework in which a general definition of internal control, standards, and criteria for internal control can be drawn up by companies to assess their control systems.

The purpose of internal control is to maintain the organization's wealth / secure assets, check the accuracy and correctness of accounting data, encourage efficiency. Encourage compliance with management policies. The internal control system has 6 basic elements, namely, honest and competent employees, proper procedures for granting authority, complete documents and records, adequate physical control of assets and records, independent verification (Hall, 2001). According to the Committee of Sponsoring Organization of the Tread way Commission (COSO), the internal control of a business unit consists of components of the control environment, risk assessment, information and communication, control activities, and monitoring.

\subsection{Financial statements}

The financial report is a summary of a recording process, which is a summary of financial transactions that occurred during the financial year concerned (Baridwan, 2009). The purpose of financial statements for general purposes is to provide information about the financial position, performance, and cash flows of the company that is useful for the majority of users of the report in order to make economic decisions and demonstrate the attitude of management's responsibility for the use of the resources entrusted to them. Meanwhile, according to the Indonesian accounting ties in the 2015 Financial Accounting Standards (PSAK) No. 1 paragraph 10, explains that "the objective of financial statements is to provide information about the financial position, financial performance and cash flows of an entity that is useful to a wide range of users of financial statements in making economic decisions."

By obtaining the financial statements of a company will be able to know the overall financial condition of the company. Then, the financial statements are not only enough to read, but also must be understood and understood about the company's current financial position. Government Regulation No. 71 of 2010 concerning Government Accounting Standards stated that the qualitative characteristics of financial statements are normative measures that need to be realized in accounting information so that it can fulfill its objectives. The four characteristics are: relevant, reliable, comparable, and understandable.

\subsection{Framework}

With the accounting system, the risk of errors and recording or calculation errors can be 
minimized thereby reducing the possibility of companies experiencing errors in financial statements. A quality system, designed, built, and able to work well if the parts that are integrated with the system can operate in accordance with their respective duties and responsibilities. One part of the accounting information system that supports the information work system is internal control.

The influence of information technology on the quality of financial reports, namely the increase in the use of information technology, the quality of financial reports will also increase (Nurilah, 2014). The utilization of information technology will be very helpful in assisting the processing of transaction data and company reports. The utilization of information technology which includes computer technology and communication technology in corporate financial management will improve the processing of transactions and other data, accuracy in calculations, as well as the preparation of reports and other outputs in a more timely manner.

Internal control ensures the availability of accurate company accounting information. The company's accounting information will be relevant, reliable, comparable and accessible. This shows that the importance of internal control in ensuring the quality of reports. With the implementation of a good internal control system, the quality of the company's financial statements will increase. The higher the implementation of the internal control system, the higher the quality of the company's financial statements.

Based on the concept of thinking above, the researcher describes the framework of thinking for the research to be carried out. Here's a picture of the framework

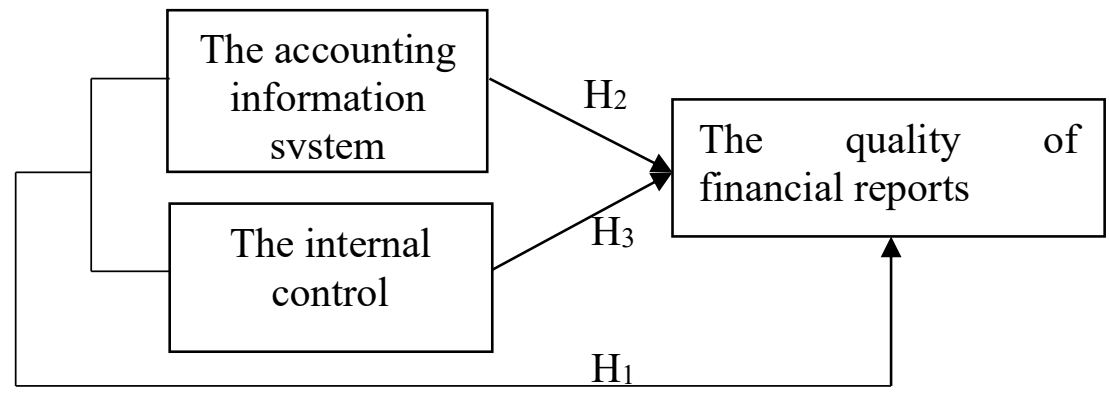

Figure 1. Framework

\subsection{Hypothesis}

The hypothesis is a temporary answer to the research problem formulation, where the problem formulation has been stated in the form of questions. It is said to be temporary because the new answer is based on relevant theory, not based on empirical facts obtained from data collection (Sugiyono, 2016).

Explanation Based on what was stated above, the hypotheses of this research are as follows:

H1 : Accounting information systems and internal control systems affect the quality of fnancial reports

$\mathrm{H} 2$ : Accounting information system affects the quality of financial statements

H3 : Internal control system effect on the quality of financial statements

\section{Research Method}




\subsection{Population and Sample}

The population in this study were employees of PT Semen Baturaja (Persero) Tbk. The sample in this study were all employees of the accounting and finance division at PT Semen Baturaja (Persero) Tbk, totaling 60 respondents. The sampling technique in this study is nonprobability sampling, namely the saturated sample. Researchers collect data by distributing questionnaires to a predetermined population. After collecting data, then determining the measurement tools used to obtain data from the elements to be investigated. In this study, the measurement tool in question is a list of statements or questionnaires. Each item of the questionnaire is a positive statement given a score of 1 to 5 that the author has provided.

\subsection{Research Variables and Operational Definitions of Variables}

The research variable is an attribute or nature or value of a person, object, or activity that has a certain variation determined by the researcher to be studied and then drawn conclusions (Sugiyono, 2016).

In this study, there are 2 research variables and an operational definition can be drawn as follows:

Tabel 1. Definition of Operational Variables

\begin{tabular}{|c|c|c|c|}
\hline Variable & Definition & Indicator & Scale \\
\hline $\begin{array}{c}\text { Accounting } \\
\text { Information System } \\
\text { (X1) }\end{array}$ & $\begin{array}{l}\text { An accounting } \\
\text { information system is } \\
\text { a series of } \\
\text { components related to } \\
\text { recording and } \\
\text { processing } \\
\text { accounting data into } \\
\text { useful information for } \\
\text { organizations in } \\
\text { making decisions. }\end{array}$ & $\begin{array}{l}\text { a. Service System } \\
\text { b. System Quality } \\
\text { c. Information Quality } \\
\text { (Mutiar, 2018) }\end{array}$ & Interval \\
\hline $\begin{array}{l}\text { Internal Control } \\
\text { System (X2) }\end{array}$ & $\begin{array}{l}\text { Internal control is a } \\
\text { process that is } \\
\text { influenced by human } \\
\text { resources and } \\
\text { information } \\
\text { technology systems, } \\
\text { which are designed to } \\
\text { help organizations } \\
\text { achieve certain goals } \\
\text { or objectives }\end{array}$ & $\begin{array}{l}\text { a. Atmosphere or Control } \\
\text { Environment } \\
\text { b. Risk Assessment } \\
\text { c. Control Activities } \\
\text { d. Information and } \\
\text { Communication } \\
\text { e. Monitoring } \\
\text { (COSO, 2013) }\end{array}$ & Interval \\
\hline $\begin{array}{l}\text { Quality of Financial } \\
\text { Statements (Y) }\end{array}$ & $\begin{array}{lr}\text { Quality of } & \text { Financial } \\
\text { Statements } & \text { is }\end{array}$ & a. Relevant & Interval \\
\hline
\end{tabular}




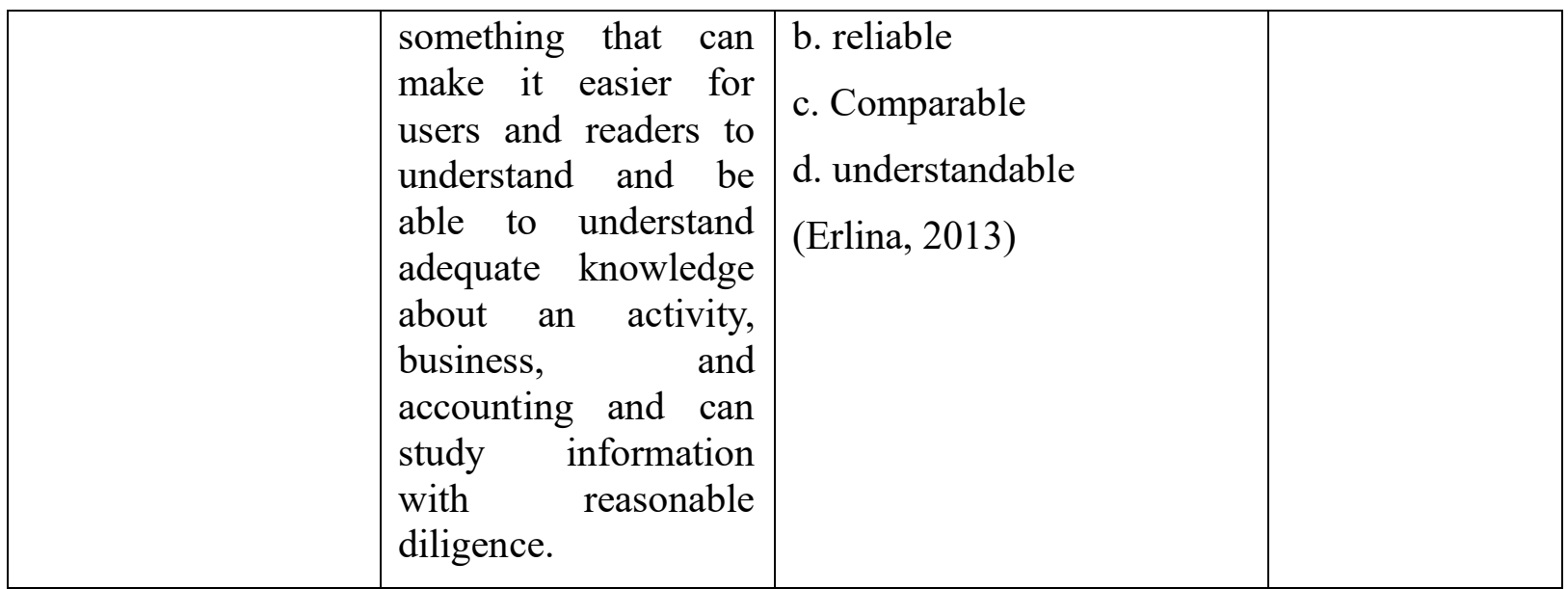

\section{Findings and Discussions}

\subsection{Validity and Reliability Test Results}

\subsubsection{Validity Test Result}

A validity test is a measure that shows the extent to which the measurement instrument is able to measure what it wants to measure. The indicator is said to be valid if the Pearson correlation is more than 0.2564 . Based on the results of data processing of accounting information system variables (X1), internal control system (X2), quality of financial reports (Y) indicates that all Pearson Correlations have a value greater than $r_{\text {table }}(0.2564)$, meaning that all questions are valid. All of these questions can be used as a valid measuring tool in the next analysis.

\subsubsection{Reliability Test Result}

Reliability is a measure that shows consistency in measuring instruments in measuring the same symptoms on other occasions. Where the questionnaire is said to be reliable if the Cronbach Alpha value is greater than $>0.60$ while if the Cronbach Alpha value $(\alpha)<0.60$ then the indicator used by the variable it is not reliable. The results of the reliability test are as follows:

Table 2. Reliability Test Results

\begin{tabular}{|c|l|c|c|c|}
\hline No & \multicolumn{1}{|c|}{ Variabel } & $\begin{array}{c}\text { Cronbach } \\
\text { Alpha } \\
(\alpha)\end{array}$ & $\begin{array}{c}\text { Alpha } \\
\text { Value }\end{array}$ & Reliability Results \\
\hline 1 & $\begin{array}{l}\text { Accounting Information System } \\
(\mathrm{X} 1)\end{array}$ & 0,725 & 0,60 & Reliable \\
\hline 2 & Internal Control System (X2) & 0,479 & 0,60 & Reliable \\
\hline 3 & $\begin{array}{l}\text { Quality of Financial Statements } \\
(Y)\end{array}$ & 0,484 & 0,60 & Reliable \\
\hline
\end{tabular}

Source: SPSS Data Result Processing Version 23 
Based on table 2 above, all of the Cronbach Alpha values exceed the Alpha values. Because the value of all Cronbach Alpha is greater at 0.60 , it can be concluded that all instruments are declared reliable.

\subsection{Hypothesis Test}

\subsubsection{F Test}

Uji F (Simultan) bertujuan untuk mengetahui apakah pengaruh sistem informasi akuntansi dan sistem pengendalian intern terhadap kualitas laporan keuangan. Adapun hasilnya dapat dilihat pada tabel berikut ini.

Table 3. F. Test Results

ANOVA $^{\mathrm{a}}$

\begin{tabular}{|l|l|r|r|r|r|r|}
\hline \multicolumn{2}{|l|}{ Model } & Sum of Squares & Df & Mean Square & F & Sig. \\
\hline \multirow{3}{*}{1} & Regression & 384,603 & 2 & 192,302 & 26,494 &, $000^{\mathrm{b}}$ \\
\cline { 2 - 7 } & Residual & 413,730 & 57 & 7,258 & & \\
\cline { 2 - 7 } & Total & 798,333 & 59 & & & \\
\hline
\end{tabular}

a. Dependent Variable: FinancialReportQuality

b. Predictors: (Constant), SPI, SIA

\section{Source: SPSS Data Processing Results Version 23}

The $F$ test is said to be influential if the Fcount value is greater than $F_{\text {table }}>3.15$ while if the Fcount value is less than $F_{\text {table }}<3.15$ then the $F$ test is said to have no effect. Based on table 3 . above, it can be explained that the value of $\mathrm{F}_{\text {count }} 26.494>\mathrm{F}_{\text {table }} 3.15$, then $\mathrm{H} 0$ is rejected and $\mathrm{H} 1$ is accepted. This shows that there is a positive and significant influence between the variables of the accounting information system and internal control system on the quality of the financial statements of PT Semen Baturaja (Persero) Tbk.

\subsection{2 t Test}

The t-test (Partial) aims to determine whether the influence of individual/partial accounting information systems and internal control systems on the quality of financial reports. The results can be seen in the following table

Tabel 4. $t$ Test

\section{Coefficients ${ }^{\mathrm{a}}$}

\begin{tabular}{|l|l|c|c|c|c|c|}
\hline \multicolumn{2}{|l|}{} & \multicolumn{2}{|c|}{ Unstandardized Coefficients } & $\begin{array}{c}\text { Standardized } \\
\text { Coefficients }\end{array}$ & \\
\cline { 3 - 5 } \multicolumn{2}{|l|}{ Model } & B & Std. Error & Beta & T & Sig. \\
\hline 1 & (Constant) & 12,221 & 5,408 & & 2,260 &, 028 \\
\hline
\end{tabular}




\begin{tabular}{|l|l|r|r|r|r|r|}
\hline SIA &, 066 &, 092 &, 074 & 2,724 &, 007 \\
\cline { 2 - 7 } & SPI &, 348 &, 054 &, 664 & 6,477 &, 000 \\
\hline
\end{tabular}

a. Dependent Variable: FinancialReportQuality

\section{Source: SPSS Data Processing Results Version 23}

The t-test is said to be influential if the tcount value is greater than ttable $>1.67065$, while if the tcount value is less than ttable $<1.67065$, the $\mathrm{t}$-test is said to have no effect. Based on table 4 above, it can be explained that each variable influence of the accounting information system and internal control system individually/partially on the quality of financial reports is as follows:

1. The influence of the accounting information system variable (X1) individually/partially on the quality of financial reports. Based on table 4.13 above, it can be seen that tcount for the accounting information system variable $(\mathrm{X} 1)$ is $=2.724$ on the quality of financial reports (Y) this means tcount $2.724>$ ttable 1.67065 with a significance of $0.007<0.05$ then $\mathrm{H} 0$ is rejected and $\mathrm{H} 2$ is accepted. It means that there is a positive and significant effect of the accounting information system (X1) on the quality of financial reports (Y).

2. The influence of the internal control system variable (X2) individually/partially on the quality of financial reports. Based on table 4.13 above, it can be seen that tcount for the internal control system variable $(\mathrm{X} 2)$ is $=6.477$ on the quality of financial reports $(\mathrm{Y})$ this means tcount 6,477>t table 1.67065 then $\mathrm{H} 0$ is rejected and $\mathrm{H} 3$ is accepted. It means that there is a positive and significant influence of the internal control system (X2) on the quality of financial reports (Y).

\subsection{Discussion}

Based on the results of the $\mathrm{F}$ (simultaneous) test, it can be seen that the calculated $\mathrm{F}$ value is $26,494>$ Ftable 3.15 , with a significance of $0.000<0.05$, then $\mathrm{H} 0$ is rejected and $\mathrm{H} 1$ is accepted. This shows that there is a positive and significant influence between the variables of the accounting information system and internal control system on the quality of the financial statements of PT Semen Baturaja (Persero) Tbk.

This shows that the accounting information system and the Internal Control System have a relationship with the quality of financial reports, in other words, there is a positive relationship to get the quality of effective financial reports, namely the existence of an accounting information system and an internal control system at PT Semen Baturaja (Persero) Tbk.

This research is supported by previous research which shows that the accounting information system and internal control system have a simultaneous effect on the quality of financial reports (Widiyaningtias, 2014).

\subsubsection{The Effect of Accounting Information Systems on the Quality of Financial Statements}

Based on the results of the t-test conducted that the accounting information system (X1) there is a positive and significant coefficient between the accounting information system and the quality of financial reports. It can be seen that tcount for the accounting information system variable $(\mathrm{X} 1)$ is $=2.724$ on the quality of financial reports $(\mathrm{Y})$ this means tcount $2.724>$ 
ttable 1.67065 with a significance of $0.000<0.05$ then $\mathrm{H} 0$ is rejected and $\mathrm{H} 2$ is accepted. It means that there is a positive and significant effect of the accounting information system (X1) on the quality of financial reports (Y).

This shows that the higher the accounting information system, the more effective the quality of financial reports. The accounting information system is used to obtain accurate, effective and efficient information needed by companies to obtain quality financial reports because one of the benefits of an accounting information system is to obtain quality financial reports for companies, one of which is PT Semen Baturaja (Persero) Tbk. To get the quality of financial reports effectively, an adequate accounting information system is needed so that activities within the company run quickly, easily, and precisely according to purpose.

This is in accordance with Theory Of Reasoned Action (TRA) which is a model of acceptance of information technology systems that will be used by users. The purpose of the TAM model is to be able to explain the main factors of the behavior of information technology users on the acceptance of the use of information systems. This model is expected to illustrate that the use of information systems will be influenced by the usability variable and the ease of use variable.

If the accounting information system has been used and utilized by PT Semen Baturaja (Persero) Tbk effectively, it will make it easier and faster to obtain and process the data needed so that employees can carry out their duties on target in accordance with the SOPs applied in the company, where SOPs are one of the a form of accounting information system so that financial reports can be of effective quality. So it can be said that the accounting information system affects the quality of financial reports. The SOP used by PT Semen Baturaja (Persero) Tbk is the Whistleblowing System (WBS) which is a system that regulates the procedures for complaints and disclosure of violations at PT Semen Baturaja (Persero) Tbk. This is in line with previous research which also showed that accounting information systems have a significant effect on the quality of financial reports (Deviani, 2013).

\subsubsection{The Effect of Internal Control System on the Quality of Financial Statements}

Based on the results of the t-test, it can be seen that tcount for the internal control system variable $(\mathrm{X} 2)$ is $=6.477$ on the quality of financial reports $(\mathrm{Y})$ this means tcount6,477 $>\mathrm{t}$ table 1.67065 with a significance of $0.000<0.05$ then $\mathrm{H} 0$ is rejected and $\mathrm{H} 3$ accepted. It means that there is a positive and significant influence of the internal control system (X2) on the quality of financial reports $(\mathrm{Y})$. this means the level of implementation of the internal control system carried out by employees is high so that it can improve the quality of the company's financial statements.

The internal control system is intended to provide adequate assurance in order to achieve the effectiveness and efficiency of the objective of financial reporting reliability on the company's activities to achieve effective and efficient management. According to Government Regulation (PP) Number 60 of 2008 that the internal control system related to financial statements is a process designed to provide adequate assurance on the reliability of financial statements in accordance with company accounting standards, which will produce quality financial reports. This means that in a good internal control system, good quality information will be realized, so that the internal control system runs optimally, PT Semen Baturaja (Persero) Tbk needs awareness from all parties, both leaders and subordinates for its implementation so that it can produce good quality financial reports as well. The results of this study support the results of previous studies which stated that there was an influence 
between the internal control system on the quality of financial reports (Komalasari, 2016).

\section{Conclusion and Suggestions}

\subsection{Conclusion}

This study analyzes the effect of accounting information systems and internal control systems on the quality of financial reports. Respondents in this study amounted to 60 employees of PT Semen Baturaja (Persero) Tbk accounting and finance department. Based on the results of the study as described in the previous chapter, the following conclusions can be drawn:

1. Accounting information systems and internal control systems have a simultaneous positive effect on the quality of financial reports. This shows that there is a positive relationship to get the quality of effective financial reports, namely the existence of an accounting information system and an internal control system.

2. The accounting information system has a positive effect on the quality of financial reports. This shows that the higher the accounting information system, the more effective the quality of financial reports.

3. The internal control system has a positive effect on the quality of financial reports. This shows the level of implementation of the internal control system carried out by employees is high so that it can improve the quality of the company's financial statements.

\subsection{Suggestions}

Research on the quality of financial statements in the future is expected to be able to provide higher quality results, taking into account the following suggestions:

1. Research is advised to add other independent variables that are not yet in this study and to expand the object of research so that research results are more likely to be concluded in general.

2. For further research, so that more references in the research such as; books, journals, previous research, and others so that they can expand the range of research and are interesting to discuss in the future.

3. For companies, companies are expected to publish annual financial reports every year so that they can be examined by further researchers.

\section{References}

Baridwan, Z. (2009). Sistem Akuntansi Penyusunan Prosedur dan Metode. Yogyakarta: $Y K P N$.

COSO. (2013). Internal Control-Integrated Framework. Diakses Pada 13 Oktober 2020. https://www.coso.org/

Davis, F. D. (2018). Perceived Usefulness, Perceived Ease of Use, and User Acceptance of Information Technology. MIS Quarterly, 13(5), 319-339.

Deny, K. A. (2014). Sistem Informasi Akuntansi. Edisi Sembilan. Salemba Empat.

Deviani. (2013). Pengaruh Kapasitas Sumber Daya Manusia, Pemamfaatan Teknologi Informasi Akuntansi, Dan Pengawasan Keuangan Terhadap Nilai Informasi Pelaporan Keuangan Pemerintah Daerah. Jurnal WRA 1 (1) : 21-45. 
Effendi, D. (2013). Pengaruh Sistem Informasi Akuntansi dan Kinerja Karyawan Terhadap Keefektifan Pengendalian Internal Di Koperindo Jatim Cabang Nganjuk. Universitas Muhammadiyah Ponorogo, Prodi S1 Akuntansi, 3.

Erlina, R. (2013). Akuntansi Keuangan Daerah Berbasis Akrual. Penerbit: Brama Ardian.

Ghozali, I. (2013). Aplikasi Analisis Multivariate Dengan Program IBM SPSS. Edisi Ketujuh. Badan Penerbit Universitas Diponegoro, Semarang.

Gujarati. (2012). Dasar-dasar Ekonometrika. Edisi Kelima. Jakarta: Salemba Empat.

Hall, J. A. (2001). Sistem Informasi Akuntansi, Terjemahan Oleh Amir Abadi Yusuf. Edisi Pertama. Jakarta: Penerbit Salemba Empat.

Icek, A. (1991). The Theory of Planned Behavior Organizational Behavior and Human Decision Processes. Organizational Behavior and Human Decision Processes, 50(2), 179211.

Jogiyanto. (2007). Sistem Informasi Keprilakuan. Edisi Revisi. Andi Offset.

Komalasari. (2016). Pengaruh Sistem Akuntansi Keuangan Daerah (SAKD) dan Sistem Pengendalian Intern Pemerintah (SPIP) Terhadap Kualitas Laporan Keuangan (Study Empiris pada DPPKAD Kabupaten Subang. E-Journal S1 Ak Universitas Pasundan.

Krismiaji. (2015). Sistem Informasi Akuntansi. Edisi Keempat. Unit Penerbit dan Percetakan AMP YKPN, Yogyakarta.

Mokoginta, N., \& Lambey, L. (2017). Pengaruh Sistem Pengendalian Intern Dan Sistem Akuntansi Keuangan Daerah Terhadap Kualitas Laporan Keuangan Pemerintah. Going Concern : Jurnal Riset Akuntansi, 12(2), 874-890.

Mutiar, Y. (2018). Pengaruh Efektivitas Sistem Informasi Akuntansi Terhadap Kualitas Laporan Keuangan Pada PT. PP (Persero) Tbk. Proyek Pelabuhan Sibolga. Skripsi. Universitas Medan Area

Nurilah, A. S. (2014). Pengaruh Kompetensi Sumber Daya Manusia , Penerapan Sistem Akuntansi Pemamfaatan Teknologi Informasi , ( Studi Empiris Pada SKPD Kota Depok ). JOM FEKON Universitas Diponegoro.

Santoso, S. (2012). Statistik Parametik. Jakarta: PT Gramedia Pustaka Umum.

Sugiyono. (2016). Metode Penelitian Kuantitatif dan R\&D. Bandung: Alfabeta.

Sutrisna, K. (2020). Perusahaan Belum Sampaikan Laporan Keuangan, BEI Beri Peringatan Dan Denda. Diakses Pada 10 Oktober 2020. https://market.bisnis.com/

Tawaqal, I., \& Suparno. (2017). Pengaruh Penerapan Sistem Informasi Akuntansi , Sistem Terhadap Kualitas Laporan Keuangan Satuan Kerja Perangkat. Jurnal Ilmiah Mahasiswa Ekonomi Akuntansi (JIMEKA), 2(4), 125-135.

Widiyaningtias, E. (2014). Pengaruh Sistem Pengendalian Internal, Pemamfaatan Teknologi Informasi dan Kapasitas Auditor Internal Terhadap Kualitas Laporan Keuangan Bank Pembiayaan Rakyat Syariah Se-Jabodetabek. E-Journal Universitas Negeri Islam Syarif Hidayatullah Jakarta. 